\title{
HUBUNGAN ANTARA POLA ASUH ORANG TUA DENGAN KEMANDIRIAN BELAJAR PESERTA DIDIK
}

\author{
Panni Ance L.Tobing ${ }^{1}$, Ruth Donda Eleonora Panggabean ${ }^{2}$,Niken Farida ${ }^{3}$ \\ ${ }^{1,2,3}$ Universitas Sari Mutiara Indonesia, Indonesia.
}

Email: panniancelumbantobing@gmail ${ }^{1}$,ruthdpanggabean@yahoo.co.id ${ }^{2}$, nikenfarida94@gmail.com ${ }^{3}$

\begin{abstract}
This research aimed to determine the relationship beetwen parenting parents with the learning independence students which is implemented at the SD Negeri 066652 Medan Helvetia in OktoberNopember academic year 2019/2020. This research used approa chment that used a method of analysis correlation. The sample in this research is fourth grade students SD Negeri 066652 Medan Helvetia with the totaling 38 people. This research used data collection techniques in the form of a questionnaire and to test yhe hypothesis used product moment correlation analysis form Karl Pearson. The result of this research indicate that there is a positive relationship between parenting parents with the learning independence of class IV SD Negeri 066652 Medan Helvetia with most correlation 12,1\%.
\end{abstract}

Keywords: Parenting Parents and Learning Independence

\begin{abstract}
ABSTRAK
Penelitian ini bertujuan untuk mengetahui hubungan antara pola asuh orang tua dengan kemandirian belajar peserta didik yang dilaksanakan di SD Negeri 066652 Medan Helvetia pada bulan Oktober November 2020 Tahun Ajaran 2019/2020. Penelitian ini menggunakan pendekatan kuantitatif dengan metode yang digunakan adalah analisis korelasi. Sampel pada penelitian ini adalah peserta didik kelas IV SD Negeri 066652 Medan Helvetia dengan jumlah 38 orang. Penelitian ini menggunakan teknik pengumpulan data yaitu berupa angket dan untuk menguji hipotesis digunakan analisis korelasi product moment dari Karl Pearson. Hasil penelitian ini menunjukkan bahwa terdapat hubungan positif antara pola asuh orang tua dengan kemandirian belajar peserta didik kelas IV SD Negeri 066652 Medan Helvetia dengan besar korelasi $12,1 \%$.
\end{abstract}

Kata Kunci: Pola Asuh Orang Tua dan Kemandirian Belajar

\section{PENDAHULUAN}

Berdasarkan tujuan pendidikan nasional, salah satunya disebutkan untuk menciptakan kemandirian. Kemandirian mencakup pengertian kebebasan untuk siap tidak lagi bergantung pada orang lain. Menurut (Ali dan Asrori, 2014:107) kemandirian merupakan kemampuan melepaskan diri secara emosional terhadap orang lain terutama orang tua, mampu mengambil keputusan sendiri dan konsisten kepada keputusannya tersebut, dan bertingkah laku sesuai nilai yang berlaku di lingkungannya.

Kemandirian belajar merupakan perilaku yang ada pada diri seseorang untuk melakukan kegiatan belajar karena dorongan dari dalam diri sendiri, bukan karena pengaruh dari luar. kemandirian belajar adalah aspek yang sangat penting dalam dunia pendidikan, dimana siswa yang tidak memiliki kemandirian belajar akan sangat sulit untuk bertanggungjawab dalam segala hal terutama dalam proses pembelajaran, selain itu peserta didik tidak dapat mengambil keputusannya sendiri, dan tidak mempunyai gagasan, ide dan inisiatif dalam setiap permasalahan yang dihadapi, hal itu disebabkan karena ketergantungannya terhadap orang tua dan selalu mengandalkan orang lain.

Kemandirian belajar dapat terbentuk karena pengaruh dari beberapa faktor, seperti faktor internal yaitu faktor yang berasal dari dalam dirinya sendiri dan faktor eksternal yaitu pengaruh yang berasal dari lingkungan seperti lingkungan keluarga 
(pola asuh orang tua), sekolah, lingkungan sosial, ekonomi dan lingkungan masyarakat. Pola asuh orang tua merupakan gambaran tentang sikap dan perilaku orang tua dan anak dalam berinteraksi, berkomunikasi selama mengadakan kegiatan pengasuhan.

Santrock (2017) membagi pola asuh orang tua ke dalam tiga jenis, yakni: pola asuh authoritarian (otoriter), pola asuh authoritative (demokratis) dan pola asuh permissive (permisif). Dengan berbagai pola asuh tersebut harus disesuaikan dengan kepribadian anak karena hal tersebut berhubungan dengan sikap dan perilaku anak dalam kehidupan sehari-hari.

Namun, fenomena dilapangan menunjukkan bahwa masih terdapat peserta didik yang memiliki kemandirian belajar yang rendah, meskipun terdapat pula peserta didik yang sudah berhasil mencapai kemandirian belajar yang sesuai dengan perkembangannya. Dari 38 orang peserta didik yang telah diamati, terdapat sekitar 7 orang yang memiliki kemandirian belajar yang rendah. Perbedaan pencapaian kemandirian belajar ini disebabkan karena ketergantungan terhadap orang lain yaitu orang tua, teman, guru dan kurangnya motivasi diri untuk belajar secara mandiri.

Dan berdasarkan hasil wawancara terhadap seorang guru wali kelas di kelas IV

B yaitu Ibu Surniati, S.Pd menggambarkan permasalahan peserta didik yang memiliki kemandirian belajar yang rendah, yaitu terdapat peserta didik yang mengerjakan PR di sekolah, kurang berinisiatif dalam mencari bahan pelajaran sendiri, peserta didik hanya akan belajar jika diperintah guru, gembira jika guru tidak mengajar, mengikuti proses belajar mengajar bersifat pasif, mengobrol disaat guru menyampaikan pembelajaran dan dalam kegiatan ulangan mempunyai kesukaan untuk menyontek pekerjaan teman.

Bertolak dari fenomena tersebut maka dirumuskan permasalahan penelitian Apakah ada Hubungan antara Pola Asuh Orang Tua dengan Kemandirian Belajar Peserta Didik Kelas IV SD Negeri 066652 Medan Helvetia?.

Mengenai tinjauan pustaka pola asuh dikemukakan oleh James (2016), mengemukakan bahwa pola asuh diartikan sebagai parenting cara orang tua berinteraksi dengan anak, cara orang tua berperilaku sebagai model dihadapan anakanaknya, cara orang tua memberikan kasih sayang, menanggapi dan membantu anak mengatasi masalahnya, hangat, terbuka, mau mendengarkan secara aktif, dan realistik.

Jadi dapat disimpulkan bahwa pola asuh merupakan pola interaksi orang tua dan anak. Artinya, bagaimana sikap dan perilaku orang tua saat berinteraksi dengan anak. Termasuk cara menerapkan aturan dan mengajarkan norma-norma, memberikan perhatian dan kasih sayang, serta menunjukkan sikap dan perilaku yang baik sehingga menjadi panutan bagi anaknya.

Tentang jenis-jenis pola asuh orang tua menurut Hurlock dalam A Faqihuddin (2015), terdiri dari pola asuh otoriter, demokratis dan permisif. Pola asuh otoriter ditandai dengan cara mengasuh anak dengan aturan-aturan yang ketat, sering kali memaksa anak untuk berperilaku seperti dirinya (orang tua), kekebasan untuk bertindak atas nama diri sendiri dibatasi. Anak jarang diajak berkomunikasi dan bertukar pikiran dengan orang tua, orang tua menganggap bahwa semua sikapnya sudah benar sehingga tidak perlu dipertimbangkan anak.Pola asuh demokratis ditandai dengan adanya pengakuan orang tua terhadap kemampuan anak, anak diberi kesempatan untuk tidak selalu tergantung pada orang tua. Orang tua sedikit memberi kebebasan untuk memilih apa yang terbaik bagi dirinya, anak didengarkan pendapatnya, dilibatkan dalam pembicaraan terutama yang menyangkut kehidupan anak itu sendiri. 
Pola asuh permisif ditandai dengan cara orang tua mendidik anak secara bebas, anak dianggap sebagai orang dewasa atau muda, ia diberi kelonggaran seluas-luasnya untuk melakukan apa saja yang dikehendaki. Kontrol orang tua terhadap anak sangat lemah, juga tidak memberikan bimbingan yang cukup berarti bagi anaknya. Semua apa yang telah dilakukan anak adalah benar dan tidak perlu mendapatkan teguran, arahan atau bimbingan.

Mengenai konsep dasar kemandirian dinyatakan bahwa, kemandirian belajar adalah kegiatan belajar aktif, yang didorong oleh niat atau motif untuk menguasai sesuatu kompetensi guna mengatasi sesuatu masalah, dan dibangun dengan bekal pengetahuan atau kompetensi yang telah dimliki (Mudjiman 2011).Jadi dapat disimpulkan bahwa kemandirian belajar adalah aktivitas belajar yang didorong oleh kemauan sendiri, pilihan sendiri dan tanggung jawab sendiri tanpa bantuan orang lain serta mampu mempertanggung jawabkan tindakannya. Peserta didik dikatakan telah mampu belajar secara mandiri apabila ia telah mampu melakukan tugas belajar tanpa ketergantungan dengan orang lain.

Mengenai faktor-faktor yang mempengaruhi kemandirian menurut Ali dan Asrori (2014:118-119): a) Gen atau keturunan orang tua, orang tua memiliki sifat kemandirian tinggi sering kali menurunkan anak yang memiliki kemandirian juga. b) Pola asuh orang tua, merupakan cara orang tua mengasuh atau mendidik anak c) Sistem pendidikan, sekolah yang tidak melaksanakan demokrasi pendidikan, menekankan indoktrinasi menghambat kemandirian anak. d) Sistem kehidupan, masyarakat yang terlalu menekankan pentingnya hirarki struktur sosial, kurang menghargai manifestasi potensi anak dalam kegiatan produktif, menghambat perkembangan kemandirian.

Mengingat bahwa dalam menuju kemandirian belajar, seorang peserta didik akan senantiasa melepaskan rasa ketergantungan pada orang tuanya. Maka seorang anak menginginkan kebebasan serta kebijakan orang tua dalam bersikap dan berperilaku dalam mencapai tujuan belajarnya. Untuk itu walaupun orang tua memberikan pengawasan kepada anak, orang tua tetap perlu memberikan kebebasan secara bertahap dan menumbuhkembangkan tanggung jawab sebagai seorang peserta didik dalam mencapai kebutuhan belajarnya.

\section{METODE PENELITIAN}

Desain penelitian ini termasuk dalam penelitian ex-post facto dengan pendekatan kuantitatif.Penelitian dilakukan pada bulan Oktober - Nopember 2020 Tahun Ajaran 2019/2020 di kelas IV SD Negeri 066652 Medan Helvetia..

Populasi dan sampel dalam penelitian ini adalah seluruh peserta didik kelas IV SD Negeri 066652 Medan Helvetia Tahun Pelajaran 2019/2020 yang berjumlah 38 orang.

Defenisi operasional variabel penelitian mengenai pola asuh orang tua adalah cara orang tua memperlakukan, mendidik, dan mempersiapkan anak agar mampu berkembang menjadi pribadi yang lebih baik sehingga bisa bertanggung jawab dan mandiri. Pola asuh orang tua dijabarkan lagi menjadi tiga sub variabel. a) Pola asuh otoriter. b) Pola asuh demokratisc) Pola asuh permisif. Defenisi operasional kemandirian belajar adalah kemampuan yang dimiliki peserta didik untuk menciptakan, merencanakan, dan memilih kondisi belajar sendiri yang tidak tergantung pada penyediaan dan pengarahan guru yang terus-menerus dan tanpa bergantung pada orang lain.

Teknik pengumpulan data menggunakan angket (kuisioner) dengan skala model Likert. Sedangkan teknik analisis data menggunakan analisis statistik. Untuk 
menguji hipotesis digunakan korelasi product moment dengan bantuan SPSS 22.

\section{HASIL DAN PEMBAHASAN}

\section{Deskripsi Pola Asuh Orang Tua}

Jenis pola asuh orang tua yang dominan diterapkan dirangkum dalam diagram berikut ini:

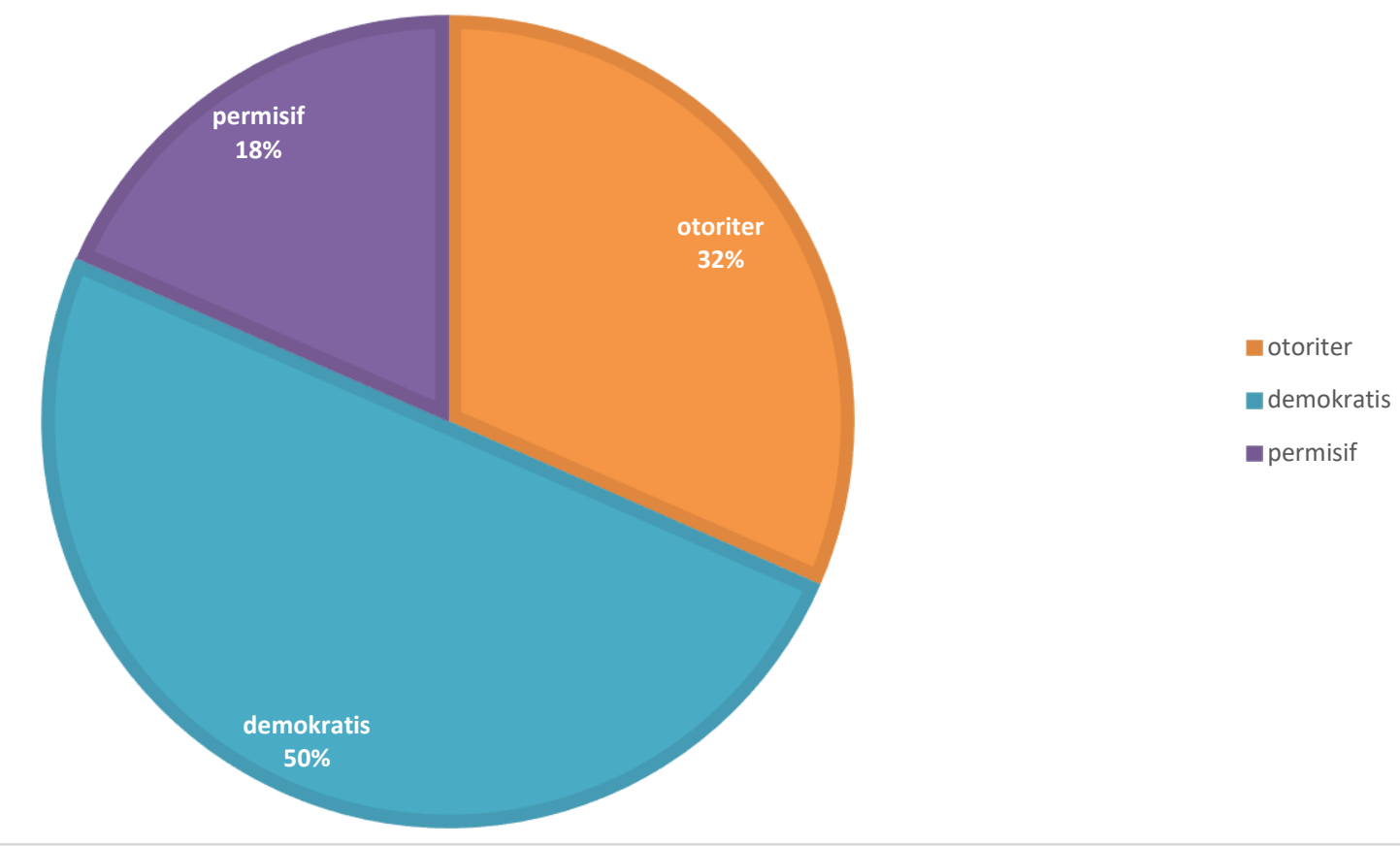

Gambar 1 Persentase Penerapan Pola Asuh Orang Tua

Berdasarkan diagram di atas, tipe pola asuh otoriter memperoleh persentase sebesar $32 \%$, pola asuh demokratis $50 \%$, dan pola asuh permisif $18 \%$. Maka dari data tersebut pola asuh demokratis memperoleh presentase paling tinggi yaitu sebesar $50 \%$. Sehingga dapat disimpulkan bahwa dari angket yang disebarkan kepada peserta didik kelas IV SD Negeri 066652 Medan Helvetia pola asuh yang dominan digunakan oleh orang tua yaitu pola asuh demokratis.

\section{Deskripsi Kemandirian Belajar}

Berikut ini adalah gambaran dari hasil penelitian tentang kemandirian belajar peserta didik yang disajikan dalam tabel distribusi frekuensi variabel kemandirian belajar peserta didik.

Tabel 1 Distribusi Frekuensi Kemandirian Belajar Peserta Didik

\begin{tabular}{cccc}
\hline Interval & F & $\%$ & Kategori \\
\hline$\geq 74$ & 2 & $5,26 \%$ & Tinggi \\
\hline $54-73$ & 29 & $76,3 \%$ & Sedang \\
\hline$\leq 53$ & 7 & $18,4 \%$ & Rendah
\end{tabular}


Jumlah $\quad 38 \quad 100 \%$

Berdasarkan tabel tersebut diketahui kemandirian belajar peserta didik Kelas IV di SD Negeri 06652 Medan Helvetia Tahun Ajaran 2019/2020 menunjukkan pada kategori tinggi sebanyak 2 orang atau 5,26\%, pada kategori sedang sebanyak 29 orang atau $50 \%$, pada kategori rendah sebanyak 7 orang atau $18,4 \%$. Untuk lebih jelasnya dapat dilihat pada diagram dibawah ini:

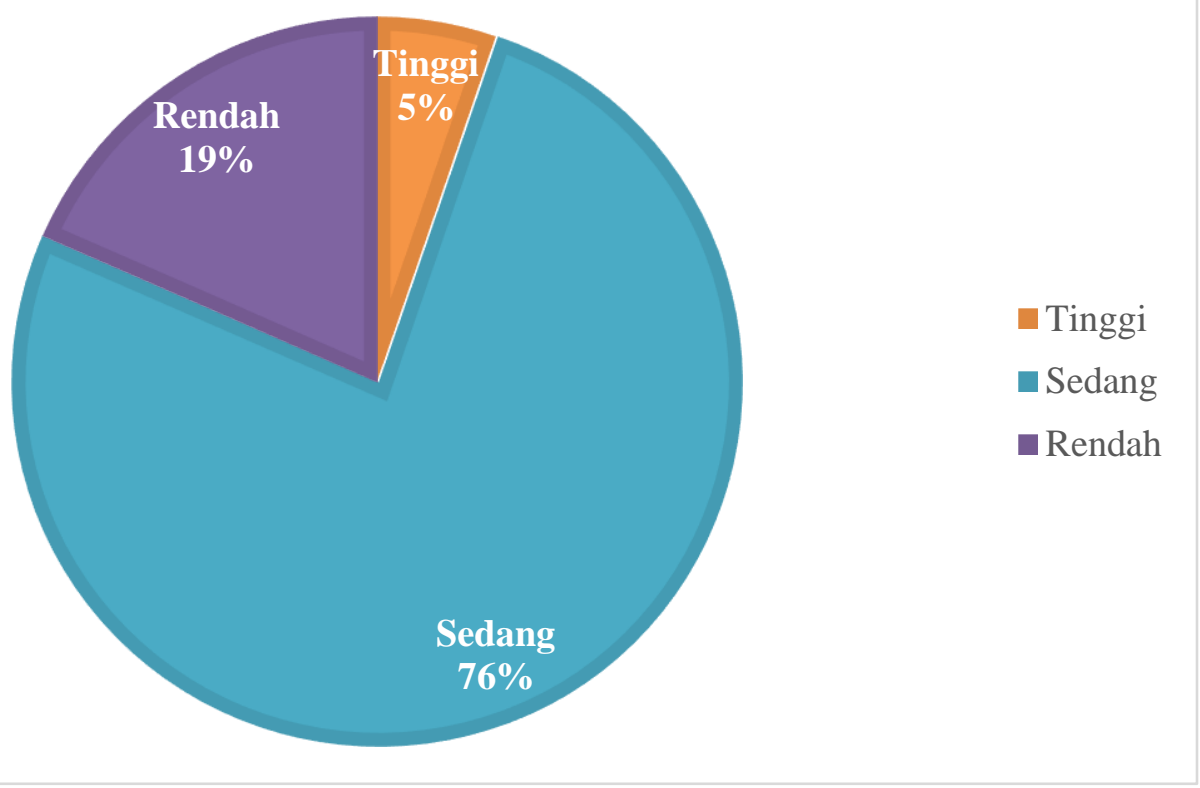

Gambar 2 Persentase Kemandirian Belajar Peserta Didik

Berdasarkan diagram tersebut diketahui kemandirian belajar peserta didik kelas IV SD Negeri 066652 Medan Helvetia Tahun Ajaran 2019/2020 menunjukkan pada kategori rendah dengan persentase $18,4 \%$, pada kategori sedang dengan persentase $76,3 \%$, pada kategori tinggi dengan persentase 5,26\%. Hasil tersebut menunjukkan bahwa kemandirian belajar peserta didik kelas IV SD Negeri 066652 Medan Helvetia berada pada kategori sedang.

\section{Pengujian Prasyarat Analisis}

Uji Normalitas

Uji normalitas bertujuan untuk mengetahui apakah data penelitian tersebut memiliki distribusi normal atau tidak normal. Berikut hasil uji normalitas KolmogrovSmirnov dengan alat bantu SPSS 22 for windows.

Tabel 2 Hasil Uji Normalitas Kolmogrov-Smirnov

NPar Tests

One-Sample Kolmogorov-Smirnov Test

Unstandardized

Residual 


\begin{tabular}{llr}
\hline $\mathrm{N}$ & & 38 \\
\hline Normal Parameters(a,b) & Mean &, 0000000 \\
& Std. Deviation & 14,27640572 \\
\hline Most Extreme Differences & Absolute &, 119 \\
& Positive &, 072 \\
& Negative &,- 119 \\
\hline Kolmogorov-Smirnov Z & &, 731 \\
\hline Asymp. Sig. (2-tailed) & &, 659 \\
\hline
\end{tabular}

Berdasarkan tabel hasil perhitungan uji normalitas menggunakan KolmogrovSmirnov di atas bahwa variabel pola asuh orang tua dengan kemandirian belajar menunjukkan angka 0,659>0,05 yang berarti data tersebut berdistribusi normal.

\section{Uji Linearitas}

Pola asuh orang tua terhadap kemandirian belajar menunjukkan $\mathrm{F}_{\text {hitung }}<\mathrm{F}_{\text {tabel }}$ yaitu $1,899<2,18$ dan signifikansi sebesar $0,87>0,05$, sehingga variabel pola asuh orang tua dengan kemandirian belajar peserta didik menunjukkan linier.

\section{Uji Hipotesis Penelitian}

Dalam penelitian ini uji hipotesis dilakukan dengan teknik analisis korelasi Product Momentdari Karl Pearson dengan menggunakan software SPSS 22.

Tabel 3 Data Hasil Korelasi Pola Asuh Orang Tua dengan Kemandirian Belajar

\begin{tabular}{|c|c|c|c|c|}
\hline \multirow[b]{2}{*}{$r_{\text {hitung }}$} & \multirow[b]{2}{*}{$\mathrm{r}_{\text {tabel }}$} & \multirow[b]{2}{*}{ Sig. } & \multicolumn{2}{|c|}{ Koefisien Determinasi } \\
\hline & & & $\mathrm{R}^{2}$ & $100 \%$ \\
\hline 0,348 & 0,329 & 0,032 & 0,121 & $12,1 \%$ \\
\hline
\end{tabular}

Pola asuh orang tua dengan kemandirian belajar peserta didik diperoleh $\mathrm{r}_{\mathrm{xy}} / \mathrm{r}_{\text {hitung }} 0,348$ lebih besar dari $\mathrm{r}_{\text {tabel }}(0,348>0,329)$ dan diperoleh nilai signifikansi sebesar 0,032 lebih kecil dari 0,05 $(0,032<0,05)$. Berdasarkan hasil tersebut, maka Ha diterima dan Ho ditolak. Besar hubungan yang diperoleh dari pola asuh orang tua dengan kemandirian belajar yaitu sebesar $12,1 \%\left(0,348^{2} \times 100=12,1\right)$. Berarti terdapat hubungan antara pola asuh orang tua dengan kemandirian belajar peserta didik kelas IV SD Negeri 066652 Medan Helvetia Tahun Ajaran 2019/2020.

\section{Pembahasan}

Hasil penelitian menunjukkan bahwa, pola asuh tipe demokratis merupakan pola asuh yang paling banyak diterapkan orang tua peserta didik kelas IV SD Negeri 066652 Medan Helvetia dibandingkan dengan pola asuh otoriter dan permisif. Pola asuh demokratis memperoleh persentase sebanyak 50\% dengan jumlah peserta didik 19 orang. Sedangkan pola asuh otoriter memperoleh persentase sebanyak 31,5\% dengan jumlah peserta didik 12 orang dan pola asuh permisif memperoleh persentase 
sebanyak $18,4 \%$ dengan jumlah peserta didik 7 orang.

Sedangkan hasil analisis untuk kemandirian belajar peserta didik kelas IV SD Negeri 066652 Medan Helvetia menunjukkan bahwa kemandirian belajar dengan kategori tinggi sebanyak 2 orang atau 5,26\%, kategori sedang sebanyak 29 orang atau $76,3 \%$ dan kategori rendah sebanyak 7 orang atau 18,4\%. Hasil tersebut menunjukkan bahwa kemandirian belajar peserta didik kelas IV SD Negeri 066652 Medan Helvetia Tahun Ajaran 2019/2020 sebagaian besar berada pada kategori sedang.

Berdasarkan hasil interpretasi data menunjukkan bahwa, penelitian ini membuktikan antara pola asuh orang tua dengan kemandirian belajar peserta didik kelas IV SD Negeri 066652 Medan Helvetia Tahun Ajaran 2019/2020 terdapat korelasi dengan jumlah yang diperoleh sebesar 12,1\% sedangkan, 87,9\% (100\% $12,1 \%=87,9 \%$ ) merupakan besar korelasi dari faktor lain yang tidak diteliti dalam penelitian ini.

Berdasarkan hasil penelitian yang telah dilakukan, dapat disimpulkan bahwa hasil perhitungan statistik dengan menggunakan analisis korelasi Product Moment membuktikan bahwa "Terdapat hubungan antara pola asuh orang tua dengan kemandirian belajar peserta didik kelas IV SD Negeri 066652 Medan Helvetia Tahun Ajaran 2019/2020".

\section{PENUTUP}

Dari hasil penelitian dapat diambil simpulan bahwa pola asuh yang lebih dominan digunakan orang tua adalah pola asuh demokratis dengan jumlah peserta didik 19 orang atau $50 \%$, Kemandirian belajar peserta didik kelas IV SD Negeri 066652 Medan Helvetia Tahun Ajaran 2019/2020 termasuk dalam kategori sedang sebanyak 29 peserta didik dari jumlah keseluruhan 38 atau 76,3\%. Dan terdapat hubungan antara pola asuh orang tua dengan kemandirian belajar peserta didik kelas IV SD Negeri 066652 Medan Helvetia Tahun Ajaran 2019/2020, dimana hasil perhitungan hipotesis dengan harga $r_{\text {hitung }}(0,348)>r_{\text {tabel }}(0,329)$ sehingga hipotesis dalam penelitian ini diterima, dengan besar korelasi yang diperoleh dari pola asuh orang tua dengan kemandirian belajar peserta didik adalah sebesar $12,1 \%$.

\section{DAFTAR PUSTAKA}

Ajat, S. (2015). Mengapa Pedidikan Karakter? Jurnal Pendidikan Karakter, No.1 Vol.1.

Ali, M., \& Asrori, M. (2014). Psikologi Remaja. Jakarta: Bumi Aksara.

Arifin, B. S., \& Rusdiana, H. A. (2019). Manajemen Pendidikan Karakter. Bandung: Pustaka Setia.

Arikunto, S. (2019). Prosedur Penelitian. Jakarta : Rineka Cipta.

Asrori. (2017). Psikologi Pembelajaran. Bandung: CV.Wacana Prima.

Ayu, R. E., Yusmansyah, \& D. U. (2018). Hubungan Antara Pola Asuh Orang Tua dengan Kemandirian Belajar Siswa. Jurnal Pendidikan SMA, 41-51.

Basri, H. (20013). Remaja Berkualitas. (problematika remaja dan solusinya). Yogyakarta: Pustaka Jaya.

Casmini. (2017). Emotional Parenting. Yogyakarta: Pilar Media.

Darajat, Z. (2015). Perawatan Jiwa Anak. Jakarta: N.V Bulan Bintang.

Desmita. (2019). Psikologi Perkembangan Peserta Didik: Panduan Bagi Orang Tua dan Guru dalam Memahami Anak Usia SD, SMP dan SMA. Bandung: Remaja Rosdakarya. 
Djamarah, \& Bahri, S. (2014). Pola Asuh Orang Tua dan Komunikasi dalam Keluarga. Jakarta: Rineka Cipta.

Euis , S. (2004). Mengasuh Anak dengan Hati. Jakarta: PT. Elex Media Komputindo.

Gregory, J. R. (2015). Tes Psikologi. Jakarta: Erlangga.

Gunarsa, \& Gunarsa. (2018). Psikologi untuk Membimbing. Jakarta: Libri.

Gunarsa, S. D. (2018). Psikologi Perkembangan Anak dan Remaja. Jakarta: PT BPK Gunung Mulia.

Hartono. (2012). Statistik Untuk Penelitian. Pekanbaru Riau: Pustaka Pelajar.

Hurlock, \& B, E. (2010). Psikologi Perkembangan: Suatu Pendekatan Sepanjang Masa Edisi ke V. Jakarta: Erlangga.

Jakni. (2016). Metodologi Penelitian Eksperimen Bidang Pendidikan. Bandung: Alfabeta.

Jayantini, S., Sulastri, M., \& Sedenayasa, G. (2014). Hubungan Pola Asuh Orang Tua Terhadap Kemandirian Belajar Siswa Kelas XI SMA Negeri 1 Sukasada Tahun Pelajaran 2013/2014. e-journal Undiksa Jurusan Bimbingan Konseling, 1-10.

Kadir. (2017). Statistika Terapan. Jakarta: Rajagrafindo Persada.

Khoirurrohman, T. (2018). Pengaruh Pola Asuh Orang Tua Terhadap Kemandirian Siswa Kelas IV SD Sekecamatan Butuh Kabupaten Purworejo. Jurnal Dialektika Jurusan PGSD, 8-17.

Mulyawati, Y., \& Christine, C. (2019). Pengaruh Pola Asuh Orang Tua Terhadap Kemandirian Belajar Siswa. Jurnal Pendidikan \& Pengajaran Guru Sekolah Dasar, 02, 21-25.

Santrock, W. J. (2011). Perkembangan Masa Hidup. Jakarta: Erlangga.

Sugiyono. (2009). Metode Penelitian Kuantitatif, Kualitatif, dan R\&D. Bandung: Alfabeta.

Sugiyono. (2019). Metode Penelitian. Bandung: Alfabeta.

Sunarty, K. (2015). Pola Asuh Orang Tua dan Kemandirian Anak. Makassar: Edukasi Mitra Grafika.

Sunarty, K. (2016). Hubungan Pola Asuh Orang Tua dengan Kemandirian Anak. Journal of EST, 152-160.

Surya, M. (2014). Psikologi Pembelajaran dan Pengajaran. Bandung: Pustaka Quaraisy.

Syahputra, D. (2017). Pengaruh Kemandirian Belajar dan Bimbingan Belajar Terhadap Kemampuan Memahami. Jurnal Penyesuaian Pada Siswa SMA Melati Perbaungan. Jurnal AT-Tasawuth, Volume II, Nomor 2. Jurnal.uinsu.ac.id.

Thoha, C. (2014). Kapita Selekta Pendidikan Islam. Yogyakarta: Pustaka Pelajar. 